This item was submitted to Loughborough's Research Repository by the author.

Items in Figshare are protected by copyright, with all rights reserved, unless otherwise indicated.

\title{
Corporate networks in post-war Britain: Do finance-industry relationships matter for corporate borrowing?
}

\section{PLEASE CITE THE PUBLISHED VERSION}

https://doi.org/10.1080/00076791.2019.1621294

\section{PUBLISHER}

(C) Taylor \& Francis (Routledge)

\section{VERSION}

AM (Accepted Manuscript)

\section{PUBLISHER STATEMENT}

This is an Accepted Manuscript of an article published by Taylor \& Francis in Business History on 25 June 2019, available online: https://doi.org/10.1080/00076791.2019.1621294

\section{LICENCE}

CC BY-NC-ND 4.0

\section{REPOSITORY RECORD}

Kern, Philipp, and Gerhard Schnyder. 2019. "Corporate Networks in Post-war Britain: Do Finance-industry Relationships Matter for Corporate Borrowing?”. Loughborough University. https://hdl.handle.net/2134/37822. 


\title{
Corporate Networks in Post-War Britain: Do Finance-Industry Relationships Matter
} for Corporate Borrowing?

\author{
Philipp Kern \\ Loughborough University London \\ p.kern@lboro.ac.uk \\ Gerhard Schnyder \\ Loughborough University London \\ g.schnyder@lboro.ac.uk
}

The Version of Record of this manuscript has been published and is available in Business

History http://www.tandfonline.com/10.1080/00076791.2019.1621294 


\begin{abstract}
The relationship between interlocking directorates and corporate finance patterns is a widelyresearched aspect of the literature on national financial systems. This literature often considers the United Kingdom to be analogous to the United States, without directly investigating the nature and impact of finance-industry relationships. Based on a handcollected dataset covering eight benchmark years between 1950 and 2010, we start filling this gap by combining historical narratives, social network-, and regression analyses. We investigate whether finance-industry relations impact corporate borrowing patterns differently across time periods. We find that network-embedding impacted corporate borrowing from the 1950s to 1970 s, but not thereafter. We also find that network structure and its function do not always evolve in parallel, highlighting limitations of purely structural approaches to understanding the link between corporate networks and firm behaviour and the importance of the historical idiosyncrasies of each country case.
\end{abstract}

Keywords: Social Networks; Finance-Industry Relationships; National Business Systems; National Financial Systems; Corporate Finance; Social Network Analysis; Banking Systems 


\section{Introduction}

The United Kingdom occupies a special place in the literature on national financial systems. Alexander Gerschenkron's (1962) seminal book explained the emergence of universal banking systems as a strategy of late industrialising nations to substitute banks for financial markets to catch up with early industrialisers. This elevated the UK-as the first industrialiser - to the status of a benchmark with a heavily market-based financial system, where firms rely on financing through well-capitalised stock markets or by issuing bonds with bank lending playing a minor role.

While this early work saw the UK as a fairly unique case, more recent research in the comparative capitalism and Law \& Finance tradition tends to describe it as a generic marketbased financial system akin to that of the USA, Canada, and other Anglo-Saxon economies (Bordo \& Sylla, 1995; Hall \& Soskice, 2001; La Porta, Lopez-de-Silanes, Shleifer, \& Vishny, 1998; Whitley, 2007). A problematic consequence of treating the UK as a generic liberal system is that insights on finance-industry relationships generated elsewhere - often the USA - are frequently assumed to also apply to the UK without empirical investigation.

Furthermore, the literature's common distinction between bank-based and marketbased systems may obscure the more important underlying aspect of long-term versus shortterm financing of corporations. Although bank loans are typically an important source of long-term finance in some countries, financial markets too can provide 'patient capital' (Deeg et al., 2016). Therefore, in this paper, we focus on long-term borrowing by corporations - as opposed to short-term financing — rather than the narrower aspect of long-term bank lending.

A central characteristic of finance-industry relationships are interlocking directorates, i.e. the links created between firms by directors who sit on multiple boards. Such interlocks have been shown to affect lending and corporate finance: banks lend more to firms they have board interlocks with and, conversely, firms with ties to banks borrow more (Davis \& 
Mizruchi, 1999; Mizruchi \& Stearns, 1994; 2002; Mizruchi, Stearns, \& Marquis, 2006).

Research has confirmed this relationship in countries as disparate as the USA and Germany, suggesting that it holds true not just across Anglo-Saxon countries, but across financial systems. Yet, the historically unique development of the British financial system should cast doubt on generalisations in this regard. Indeed, recent research on the history of banking systems (Fohlin, 2012) reasserts the uniqueness of the UK's model, including the rarity of interlocking directorates between finance and industry (see also Windolf \& Nollert, 2001), which starkly contrasts with continental European cases such as Germany (Fohlin, 2007) and Italy (Vasta, Drago, Ricciuti, \& Rinaldi, 2017). This raises questions over the evolution of finance-industry relationships over time and whether they have the same effect on bank lending and corporate borrowing in the UK as in other countries. We therefore seek to answer the following research questions related to finance-industry ties and a more general network effect on corporate borrowing:

Do direct and indirect finance-industry ties affect levels of corporate borrowing?

Does the borrowing behaviour of network neighbours affect corporate borrowing?

Prior research on the UK company network in general and finance-industry relations in particular tends to either only provide snapshots of interlocking directorates (Scott, 1987) or simply describe trends over time inferring their impact on borrowing patterns, if at all, from historical accounts rather than using firm-level accounting data to conduct more formal tests (Schnyder \& Wilson, 2014; Wilson, Buchnea, \& Tilba, 2017; Windolf \& Nollert, 2001). Braggion (2005) investigates the impact of board interlocks and proximity to banks on firm performance more directly, but only for a short period at the turn of the $20^{\text {th }}$ century. As the impact of interlocks on corporate finance behaviour may change over time (Mizruchi et al., 2006), such indirect and cross-sectional approaches are unsatisfactory. We fill this gap by providing, to our knowledge, the first systematic and longitudinal analysis for the UK of the 
relationship between a company's embedding in the interlocking directorate network and its use of long-term debt to finance its operations. We attempt to answer the following additional research question regarding the temporal nature of network functionality:

Does the effect of network ties change over time, in particular as financial firm strategies and non-financial companies' corporate finance strategies evolve?

Our work can therefore be situated as part of a 'second generation' of research on interlocking directorates (Cronin, 2011), which seeks to empirically investigate network effects on firm behaviour in order to more fully address the 'so what?' question (Mizruchi, 1996) ${ }^{1}$

We apply a mixed methods approach that combines exploratory social network analysis with regression analysis to understand both the structure and the function of financeindustry ties in Britain between 1950 and 2010. Our dataset consists of the 50 largest financial firms and 200 largest non-financial firms in eight census years across the period.

We make three contributions to research in this area. First, we provide what is to our knowledge the most in-depth account of post-war finance-industry relationships in the UK to date. Second, we go beyond mapping and describing the network patterns by empirically testing whether corporate borrowing is related to interlocking directorates. Our results suggest that British corporate finance patterns are related to board interlocks only in historically exceptional circumstances, suggesting a less relationship-based system than that of the US. The UK should therefore not be seen as a generic market-based financial system. Third, our results hint at the importance of going beyond a purely structural analysis of corporate networks by investigating their effect. We find evidence of changes in the impact of network ties on corporate finance patterns over time that are not paralleled by changes in

\footnotetext{
${ }^{1} \mathrm{We}$ are grateful to an anonymous reviewer for this point.
} 
the network's structural features. We also find phases where the network structure changes, but the effect of network ties on borrowing remains the same. Beyond our country case, this highlights the need to understand corporate networks as well as national financial systems in historical and geographical context.

\section{Theory: The Role of Interlocking Directorates in Corporate Finance}

The role of board-level links between finance and industry has been debated since the beginning of the $20^{\text {th }}$ century. American politicians and commentators at the time were concerned with the outsized influence of bankers, who were seen to create a 'money monopoly' or 'money trust' to tightly control access to capital via interlocking directorates. Although such fears have abated, the centrality of financial institutions in corporate networks has been confirmed for most developed countries (Davis \& Mizruchi, 1999; Vasta \& Baccini, 1997; Windolf, 2005; Windolf \& Nollert, 2001) as well as some developing countries (e.g. Musacchio \& Read, 2007). Research has focused on the effects of bank centrality, in particular lending patterns and corporate finance behaviours (Mintz \& Schwartz, 1985a), and whether having bankers on the board has a positive or negative effect on the firm. This section provides an overview of these debates.

The literature differentiates two views of the purpose of finance-industry interlocks. The resource dependence approach (Selznick, 1949) sees organisations as co-opting financiers onto their boards in order to establish personal relationships and secure access to key resources. A related view holds that companies co-opt bankers onto their boards to acquire financial expertise - particularly before the professionalisation of the in-house finance function since the 1970s (Mizruchi et al., 2006).

A second approach sees interlocks not as co-optation, but as a mechanism to monitor or control an organisation (Mizruchi, 1996). In this view, bankers sit on the board of 
companies they lend to in order to monitor their credit lines — which is of particular importance in capital-intensive industries (Windolf, 2005). There are several flavours of this approach. A more extreme version is the 'bank control thesis,' suggesting that banks use board seats to extract rents through asset stripping and similar strategies (Fitch \& Oppenheimer, 1970; Kotz, 1978). The more moderate variant, the 'bank hegemony' model (Mintz \& Schwartz, 1985b), acknowledges banks' power but sees them exercising it through guidance and boundary setting for managerial action rather than overt control. Here, board interlocks are primarily understood as a communication mechanism (Mizruchi, 1996). Whichever view one subscribes to, the implication of finance-industry interlocks is that they influence non-financial companies' finance patterns by facilitating access to debt and providing financial expertise.

Several studies have empirically investigated these claims. They found that corporate finance patterns are shaped by the kind of bankers companies have on their boards: investment bankers are associated with bond issues and commercial bankers with short-term debt (Stearns \& Mizruchi, 1993, 1994). Some research suggests that industrial companies actively seek to appoint bankers to their boards when they are in financial difficulties (Davis \& Mizruchi, 1999; Mizruchi \& Stearns, 1988), thereby increasing the availability of shortterm funding (Richardson, 1987; Stearns, 1986). Similarly, Ratcliff (1980) has shown that banks with more network ties tend to lend more to industry, while those with fewer ties tend to specialize in the mortgage market, suggesting that bank-industry ties increase nonfinancial firms' access to finance.

Recent contributions have sought to understand when finance-industry links are best understood from a resource dependence, bank hegemony, or bank control perspective. Evidence suggests that access to finance via board interlocks can substitute for welldeveloped financial markets, making personal relationships an important resource in 
emerging economies to access finance at all (Musacchio, 2009) or at preferential conditions (Laeven, 2001; Rajan \& Zingales, 1996; Kroszner \& Strahan, 2001). Rubio-Mondéjar and Garrués-Izurzun (2016) show how institutional weakness in Spain allowed banks to use board interlocks to consolidate power and limit economic competition.

Hence, despite different theoretical underpinnings, all theories suggest that stronger ties with financial firms will have a positive impact on borrowing in non-financial firms. Therefore, we hypothesise:

Hypothesis 1: The more a non-financial firm is interlocked with financial sector firms, the higher its level of borrowing.

This hypothesis assumes a direct effect of finance-industry ties on firm-level finance patterns, i.e. borrowing is increased by a financier sitting on a firm's board or a person affiliated with the firm sitting on the financial firm's board. Yet, weak ties ("friend of a friend") may also have an more important impact by diffusing information or organisational practices via intermediaries (Granovetter, 1973), affecting behaviours related to mergers (Haunschild, 1993) or finance decisions (Mizruchi \& Stearns, 1994; Mizruchi et al., 2006). This suggests a more general network effect than the one underlying hypothesis 1 , namely that even firms without direct banking ties may benefit from indirect ties with financial sector firms. In particular, the stronger a company's ties to firms that rely on debt, the more likely the company is to rely on debt financing as well (Mizruchi et al., 2006). We therefore hypothesise a more general network effect on borrowing patterns:

Hypothesis 2: The higher the use of debt among a firms' connections, the stronger the use of debt by the focal firm.

The literature also suggests that both the structure and the function of finance-industry networks change over time. Changing corporate finance strategies and changing lending 
strategies of financial firms may affect the network structure via their propensity to interlock with each other. Evidence from the US in the 1980-90s suggests that changes in board links with industrial firms followed a strategic reorientation of American banks from interest-based towards fees-based activities (Davis \& Mizruchi, 1999). Similar effects have been found in other countries and periods, including the financial crisis of the 1920s leading Dutch banks to refocus their strategy from industry lending to trade finance, with a corresponding decline in network density (Westerhuis, 2014).

Much less studied, but theoretically just as important, is the changing impact of finance-industry links. Evidence for the US suggests that increasing professionalisation of banking and of the corporate finance function within firms has made personal relationships less important in recent decades (Mizruchi et al., 2006). A similar phenomenon may be observed in Britain, where the main financial centre - the City of London - has shifted from a distinctly informal, relationship, and trust-based form of 'gentlemanly capitalism' towards a highly professionalised global industry (Thompson, 1997). As we discuss in more detail in section 3, the 1986 'big bang' financial market reforms led to British banks moving away from commercial lending while fostering new corporate strategies — such as shareholder value management - that privilege market-based approaches to financing over relationshipbased ones (Deeg et al., 2016; van der Zwan, 2014; Froud et al., 2006). These trends imply a decline in the importance of relationships for corporate finance, leading us to hypothesise that finance-industry ties should matter more strongly before the 'big bang' reforms than thereafter:

Hypothesis 3: Network effects on corporate borrowing are stronger before the 1986 reforms than after.

\section{Historical Context: Key Features of the British Banking System}


The City of London started to emerge as the dominant force in British banking towards the end of the $19^{\text {th }}$ century after a wave of mergers created large joint stock banks with nationwide reach. While the larger resources and branch networks of these banking houses enabled a national market for short-term business finance, the centralization of power in the London headquarters also eroded links with local business (Collins, 1995). Although the banks saw it as part of their function to provide funding to private enterprise (Cassis, 1985), they generally did so at a lower level and at shorter terms than their American, German, and Japanese counterparts (Kennedy, 1987). British commercial banks also stayed almost completely out of the investment banking business, avoiding taking long-term equity positions in industrial firms, which may also constitute a source of 'patient capital' for firms (Deeg et al., 2016). The sector was thus highly specialized, despite universal banking being allowed (Fohlin, 2012). Board-level interlocks between finance and industry were rare in this period, with only nine percent of directors from the country's leading banks also sitting on industrial boards (Collins, 1995).

The lack of deep and long-term engagement with industry can be largely attributed to the historical development of British industry. As the first industrialising nation, the UK not only developed well-capitalized stock markets early on to provide funding to industry, but the success and size of British industrial firms of the time also allowed them to self-finance much of their activities (Gerschenkron, 1962). Universal banking with strong ties to industry is usually seen to have developed in late-industrializing countries as a means of accelerating industrial development (Chandler, 1990; Gerschenkron, 1962). Consequently, the British financial sector developed an outward orientation early on. By the inter-war era, 'gentlemanly capitalism' of the City of London-while reliant on informal relationships for its domestic business - was predominantly focused on overseas business, with merchant 
banks getting accused of being "better informed on conditions in Latin America than in Lancashire or Scotland" (Cain \& Hopkins, 1993, p. 19).

\subsection{Turning Inward: 1945-1980}

World War II marked the beginning of a reorientation towards domestic activity, both in lending and stock market finance. War-time capital export controls, sales of British overseas assets, and continued capital issue restrictions hastened the decline of London as a leading financial centre and depressed international demand for the City's services. By the late 1940s, about $90 \%$ of securities listed on the London stock exchange were domestic, compared to $8 \%$ in 1913 (Thomas, 1978). Merchant banks began to more fully participate in those issues and stock exchange reforms increased financial disclosure requirements for listed firms, making the City a more important provider of industry finance in the post-World War II era (Morgan \& Thomas, 1962).

Bank lending to industry also expanded in scale and scope in this period. While bank borrowing accounted for just over half of all externally raised finance at the beginning of the 1960s, this proportion rose to almost two-thirds in the 1970s (Committee of London Clearing Bankers, 1978). This expansion occurred on the back of two factors. First, 1971 saw the relaxation of some credit controls that, until then, had aimed to reign in recurring inflation through restrictive macro-economic policy (Pollard, 1992). Although firms rarely used more than two-thirds of their short-term credit facilities (Thomas, 1978), the partial lifting of credit controls enabled more flexible and expansive approaches for lending.

The increased reliance of British industrial firms on bank borrowing may also reveal a trend that has been observed in the US, where slowing growth from the mid-1960s onwards reduced retained earnings and made companies more reliant on banks loans, leading to a 
stronger influence of American banks on industry (Davis \& Mizruchi, 1999; Stearns, 1986). A similar process may have unfolded in the UK.

A second driver of increasing lending to industry was that the scope of bank lending expanded from providing little more than overdraft facilities and 'cash on call' to include medium-term credit alongside new services such as leasing and factoring. Leasing developed particularly rapidly in this time, with clearing banks emerging as the preeminent suppliers of these services by the mid-1970s (Committee of London Clearing Bankers, 1978). Indeed, contemporaneous sources suggest that there were few limits on bank lending in this period; if anything, the economic difficulties of the 1970s limited the take up of widely available credit (Committee of London Clearing Bankers, 1978). Importantly, however, British banks still did not engage in the kind of long-term lending so common among their American, German, and Japanese counterparts.

Historical accounts suggest that the inward turn of British finance went together with a deepening of board-level links to industry. Some sources suggest that in 1976, 32 directors on the boards of the 50 largest industrial firms represented clearing banks (Utton, 1982), with others suggesting that 94 directors amongst those companies had ties to the City even if not necessarily representing a bank (Stanworth \& Giddens, 1975). The expansion of board interlocks in this period arguably shows how City bankers on industrial boards "were pivotal points in loose groupings of industrial, trading and financial enterprises ... act[ing], in effect, as proxies for the wider financial community; they act as the guardians of the interests of the hegemonic financials" (Scott, 1987, p. 60). These sources would therefore suggest that the deepening relationship between British finance and industry started to resemble the 'finance capital' (Hilferding, 1968) model in this post-war period.

\subsection{Global Reorientation: Post-1980}


After its election in 1979, the new Conservative government under Margaret Thatcher began a far-reaching programme of reforms and privatisations. It soon set its sights on liberalisation of financial markets, which were still subject to some of the restrictions put in place in the first half of the $20^{\text {th }}$ century. Financial market reform became a cornerstone of Thatcher's government programme, seeking to restore the City of London as the world's premier financial centre. This reform package came to be known as the 'big bang,' as it went into effect in one fell swoop in 1986 and contained a number of significant changes. The London Stock Exchange (LSE) became one of the first major stock exchanges to move from 'open outcry' to computerized trading. Fixed minimum commissions were abolished, along with the 'single capacity rule' that had strictly separated the roles of brokers, acting as agents for investors, and jobbers, who made markets and provided liquidity by holding stocks (Konzelmann, Fovargue-Davies, \& Schnyder, 2012; Lawson, 2006). It also removed access barriers, allowing non-member firms of the LSE—banks, insurance firms, and foreign investment banks - to trade directly.

Despite its primary aim of easing securities trading, the 'big bang' had knock-on effects on the wider British financial market. The late 1980s marked the end of the historically developed, yet never legally mandated, separation of deposit and merchant banking. While merchant banks had traditionally been highly risk-averse in their investments, made with their own funds, their behaviour changed dramatically after merging with retail banks as they now had access to larger deposits. British banks were also thrust into an increasingly globalised financial system, with American banks in particular emerging as competitors in Europe (Sylla, 2002; Battilossi \& Cassis, 2002). Competitive pressure together with the computerisation of banking transformed European and British banks' strategic direction. In continental Europe, this meant a pronounced shift away from the historically 
deep relationship with domestic industry towards global engagement, investment banking, and generally higher levels of risk-taking (Larson, Schnyder, Westerhuis, \& Wilson, 2011).

British banks followed suit, putting an end to the post-war engagement with domestic industry and returning to their historically-rooted global orientation. As they moved away from commercial banking activities into fees-based and investment banking, small and medium-sized businesses bore the brunt of the retreat from industrial lending. This was particularly pronounced during the global financial crisis of 2008-9, when the government went as far as committing the nation's five largest banks to a 'neo-corporatist bargain' (Financial Times, 2012; Jones \& Cohen, 2012) aimed at expanding lending to businesses.

For large non-financial companies, on the other hand, the reforms of the 1980s and changing bank strategies presented less of a challenge. With changing corporate finance strategies in that period, large businesses became less dependent on bank financing. Financial reforms as well as the 'financialisation' of the economy more generally (van der Zwann, 2014; Froud et al., 2006) meant that stock markets gained an entirely new significance for firms, exposing them to new pressures but also offering new opportunities for corporate finance - even 'financial engineering' (Froud et al., 2006; Lazonick \& O’Sullivan, 2000).

Taken together, these trends transformed the financial landscape in Britain, reducing both the supply and demand of intermediated finance. Whereas British banks reluctantly turned towards domestic markets and industrial financing when left without choice in the war and post-war period, they were quick to abandon these markets as soon as regulatory constraints were removed and global competition intensified. In parallel, financial globalisation and innovation made large non-financial companies less and less dependent on financial intermediation to access sources of funding.

\section{Data and Methodology}


We use a mixed methods approach that recognises the historically contingent nature of finance-industry relationships while also offering statistically robust evidence of the impact of board interlocks on corporate finance patterns. We investigate the relationships between non-financial companies and companies active in the financial sector, including banks and insurance companies as well as other financial services providers. This is because banks are not the only financial service firms providing non-financial firms with access to finance (e.g. Mizruchi et al., 2006). Insurance companies, for instance, have traditionally played an important — albeit in the UK limited — role in corporate finance through facilitating private placements of corporate bonds (Slaughter \& May, 2014).

We focus on the period from 1950 to 2010, combining social network- and regression analysis to investigate the impact of network interlocks between financial sector and nonfinancial firms on corporate borrowing. Our dataset consists of the board composition of the 50 largest financial ${ }^{2}$ and 200 largest non-financial firms by total assets in Britain in eight benchmark years across the period $\left(1950,1958,1976,1983,1993,1997,2003\right.$ and 2010). ${ }^{3}$

To create the sample, we relied on The Times 1000 list of the largest companies in the UK, lists compiled by other scholars (Fiedler \& Gospel, 2010), and the Thomson Reuters Datastream database. We then used existing datasets on board composition (Conyon \& Muldoon, 2006; Scott, 1987; Windolf \& Nollert, 2001), which we supplemented with data from the BoardEx database and hand-collected data from the Stock Exchange Official Yearbook (Macmillan).

\footnotetext{
${ }^{2}$ The share of banks in the financial sample declines from over half in the 1950s to about an eight in the most recent benchmark year, reflecting the shifting composition of the British financial sector. More precisely, the share of banks in our financial sample is $56 \%$ in 1950 and $1958,46 \%$ in $1976,50 \%$ in $1983,20 \%$ in $1993,26 \%$ in 1997 and 2000, and 14\% in 2010.

${ }^{3}$ The historical and longitudinal nature of this project meant that data availability was an issue in particular for accounting information. This resulted in small sample sizes for analysis for some of our regression models due to missing values. However, this is not unusual for similar studies where samples considerably below 100 are common, even for much larger countries such as the US (Mizruchi et al., 2006: Table 2).
} 
In order to describe and interpret the corporate network topography we used exploratory social network analysis (de Nooy, Mrvar, \& Batagelj, 2011). We calculated a series of network measures using the 'igraph' package for the $R$ statistical software programme, following the approach of David and Westerhuis (2014) in calculating various measures of network structure, cohesion, density, and firm-level network position. To describe the basic network structure and its cohesiveness we calculated the number of isolated firms (those without network ties), the number of marginal firms (with only one or two ties), and the size of the "major component," i.e. the largest connected sub-graph in the network. We measured network density using the average degree measure, which is calculated as the number of ties divided by the number of firms in the network (Wasserman \& Faust, 1994). We also calculated "network distance" as a measure of the ease with which information or practices can flow across the network along network ties (de Nooy et al., 2011; Wasserman \& Faust, 1994). This is defined as the average length (number of edges) of the shortest path between any two vertices (firms) in the network. Low values indicate a network in which information and practices flow quickly between different nodes. These measures of network topography are presented in Table 1.

\section{[Insert Table 1 about here]}

We then computed various measures of firm centrality in the network including Freeman degree centrality, closeness centrality, and betweenness centrality in order to assess the position of different firms in the network. The centrality rankings, reported in Tables 2 and 5, are substantively the same using the three measures in so far as the sectoral composition of the top 10 companies does not substantially change. We therefore only report the results for the betweenness measure, which takes into account not only the focal company's connectedness and local centrality, but also its position in the network. Betweenness counts the number of times a node is on the shortest path between any pair of 
other nodes in the network. As such, it is often interpreted as a measure of brokerage and information control power (De Nooy et al., 2005).

\subsection{Regression Analysis: Variables and Models}

To complement the descriptive, network-mapping part, we formally test our three hypotheses about the impact of network ties on borrowing by non-financial companies using regression analysis. To this effect, we specified the following variables and models.

\subsubsection{Independent variables}

To assess the impact of connectedness of non-financial firms to financial sector firms, we calculated a measure based on a company's proximity in the network to financial sector firms. This measure is based on the above-mentioned insight that having bankers or other financial sector executives on the board or, conversely, sending people affiliated with the company to sit on the board of a financial sector firm will facilitate access to finance through loans or bond issues. Yet, financial sector-industry ties do not need to be direct to have an impact on corporate finance, because even intermediated links will increase the ease with which loans can be obtained or debt issued (Granovetter, 1973; Mizruchi et al., 2006). Rather than measuring direct ties with financial companies, we calculate a measure of the sum of the distance (shortest path) of every non-financial firm in our sample from every financial firm. This is based on the distance matrix for each year, with higher values indicating larger distance from financial sector companies. We normalized this measure to vary between 0 and 1 ; its mean across all years is $0.27 . .^{4}$

\footnotetext{
${ }^{4}$ We ran robustness checks with two more limited measures, namely number of direct links with banks and number of direct links with financial services firms. The results are not substantively different, but the association between bank/finance-industry ties and borrowing is weaker even during the first period (19501978).
} 
To test our second hypothesis about the general network diffusion effect, we ran a network auto-regressive model as suggested by Mizruchi et al. (2006) (see below). We replicated their independent variable, which is a measure of the network effect. This variable is calculated based on the normalised distance matrices for each yearly network. We then multiply the normalized distance score for each firm with the dependent variable, namely the level of debt. This gives us a weighted debt measure, which consists essentially of the 'sum of the level of borrowing engaged in by each of a firm's network partners, weighted by the strength of the relations between the focal firm and the partners' (Mizruchi et al., 2006, p. 320). Mizruchi et al. (2006) carried out two additional transformations on the distance matrix which we refrained from. First, they capped the maximum distance between two vertices at three. They justify this transformation by the fact that their data contained few observations of distances of greater than three and that the distribution of distances was skewed after three (Mizruchi et al., 2006, p. 321). Our data does not show this pattern. Indeed, quite a large number of distance scores are greater than three and the distances for each year before normalisation are approximately normally distributed with an average greater than three in each year. Therefore, we concluded that truncating would distort the real nature of our data. Similarly, Mizruchi et al. (2006) use the inverted values of the distance matrices (namely 1, 0.5 and 0.33 instead of $1,2,3)$ to facilitate interpretation of the coefficient. We prefer keeping the original values.

We assess the third hypothesis on the declining impact of network ties on corporate borrowing over time using the same models as above. If our expectations are correct, we would expect to find no or only weakly statistically significant relationships between network embedding and borrowing behaviour of non-financial firms in the post-1986 benchmark years. 


\subsubsection{Dependent Variable and Controls}

Our hypotheses concern borrowing patterns of non-financial firms and in particular the extent to which they rely on long-term debt (as opposed to equity or retained earnings) to finance their operations. Given the longitudinal and historical nature of the study — and challenges arising from changes in accounting practices and data availability-we had to rely on simple measures. We used as our main dependent variable the amount of long-term debt divided by total assets. This variable corresponds with the most commonly used measure in similar studies, except that we use absolute levels instead of yearly changes as our data consists of benchmark years, not yearly data (cf. Mizruchi et al., 2006, p. 319). It is important to note that our dependent variable includes not only long-term loans maturing in more than one year's time, but also bond debentures. It excludes short-term loans. As such, it cannot be interpreted as a direct measure of bank lending, but rather as a measure of the extent of corporate debt finance, as opposed to equity or self-finance. This is in line with the focus in the comparative capitalism literature, which distinguishes debt finance-based from equity finance-based systems (Hall \& Soskice, 2001; Deeg et al., 2016). We therefore consider this measure to be appropriate for the questions at hand.

We include the most commonly used control variables in similar studies (Mizruchi et al., 2006; Mizruchi \& Stearns, 1994; Marquis, 2003; Kroszner \& Strahan, 2001). We include industry dummies, because debt levels may vary depending on an industry's fixed capital requirements and other industry-level factors (Talberg et al., 2008). Firm size, as measured by total assets, serves as a control because larger firms tend to have more collaterals and therefore an advantage in obtaining bank loans or issuing bonds. We also control for the ability to finance operations internally. As retained earnings are not reported for most years in our study, we use current assets as an approximation of a company's ability to generate cash 
via its working capital of which current assets are an important part. Finally, we control for the extent of equity finance measured as nominal issued capital.

Similar studies use several additional controls including a measure of financial health (e.g. interest coverage ratio), firm performance, number of employees, short-term debt (Kroszner \& Strahan, 2001), the type of ownership and control (Mizruchi \& Stearns, 1994), and percentage of financial directors on the board (Mizruchi et al., 2006). We do not include any of these controls in our models given that most of these measures are either not available at all, or only in vastly inconsistent form over time, from the publicly available sources used. The limited sample size also meant that we refrained from estimating overly complex models. Descriptive statistics for our variables for all eight years are reported in appendix 1.

\subsubsection{Statistical Models}

We first ran a simple linear regression model on the logged dependent variable to reduce heteroskedasticity problems:

$$
\mathrm{Y}=\mathrm{X} \beta+\varepsilon
$$

where $\mathrm{Y}$ is our dependent variable (long-term debt divided by total assets), $\mathrm{X}$ is a vector of independent and control variables and $\varepsilon$ an error term. ${ }^{5}$

We also ran the autoregressive network linear model suggested by Mizruchi et al. (2006) to test our second hypothesis regarding a more general diffusion effect of finance practices:

\footnotetext{
${ }^{5}$ As a robustness test, we also estimated this relationship using a binomial logit model. The results are broadly consistent with our hypotheses and results from our linear regression models, in the sense that the only significant result across all benchmark years is in 1958 where the impact of our indebtedness measure (longterm debt by assets) on the likelihood of having a bank tie is weakly significant (.1 level). This suggests that it is sometime during the 1950s and 1970s that borrowing behaviour and network ties were most strongly related, which is consistent with our OLS results. Given the limitations of the binomial logit model - it can only test the probability of direct ties with financial firms - we prefer the linear regression model. Results from this additional analysis are available from the authors upon request.
} 


$$
\mathrm{Y}=\rho \mathrm{WY}+\mathrm{X} \beta+\varepsilon
$$

where WY is the measure for the network effect on focal-firm lending practices, $\mathrm{X}$ is the vector of independent variables, and $\varepsilon$ is an error term.

We estimated this model following Mizruchi et al. (2006, p. 325) by treating WY as a separate variable that is included in the matrix X on which we then ran OLS. This model constitutes an autoregressive model in the sense that the calculation of the WY matrix includes the dependent variable. While such a 'spatial OLS' (Franzese \& Hays, 2004) approach has certain limitations regarding the independence of error terms, it has been shown that the estimates are not systematically biased due to the endogeneity issues compared to maximum likelihood estimations of the same model (see for a discussion Mizruchi et al., 2006).

\section{Results and Discussion}

Historical research suggests that the post-war period was marked by a deepening relationship between British finance and industry, even beginning to take the shape of ContinentalEuropean-style 'finance capital' (Hilferding, 1968). Our own data on the network topography broadly supports this view (see Table 1). The first three post-war decades from 1950 to 1976 were a phase of increasing network integration, which peaked sometime in the 1970s. Indeed, our census year 1976 is the one where all our network cohesion and centrality measures indicate the densest network during the period studied, and indeed for the entire $20^{\text {th }}$ century (cf. Schnyder \& Wilson, 2014; Wilson et al., 2017).

The evolution of the basic network structure illustrates the increasing cohesiveness of the network, as illustrated by the decline of isolated and marginal firms (Table 1).

Consequently, the size of the network of connected firms (major component) (from only $36 \%$ of firms in 1950, to about two-thirds thereafter) as well as its density, i.e. number of ties, 
increased throughout the period. The average degree of the network increased from a low level of 1.29 in 1950 to the highest observed level in 1976 (4.15), before dropping back to 3.04 in 1983. Similarly, network distance - the average length of the shortest path between two companies - is at its lowest in this period (3.13 in 1958). Our network measures also indicated that the second-half of the 1970s marked the high watermark of the UK interlocks network. Indeed, between 1976 and 1983 the number of isolated firms increased again from 25\% in 1976 to $29 \%$ in 1983 and the mean degree dropped from 4.15 in 1976 to 3.04 in 1983. The size of the main component declined from $73.49 \%$ to below $69.72 \%$.

Concerning firms' position in the network, the key development during this period is the increasing centrality of banks and other financial sector firms. As Table 2 shows, seven out of the ten most central companies by betweenness centrality in 1950 were financial sector firms. This number rose to nine out of ten in 1958 and 1976. Our network data therefore supports the notion that the City began to play a more important role in British industry in the post-war period, underpinned by more extensive board interlocks (Scott, 1987; Scott \& Griff, 1985).

[Insert Table 2 about here]

These descriptive results of network integration and their comparison to previous studies of the UK network (Schnyder \& Wilson, 2014; Scott, 1987; Scott \& Griff, 1985; Wilson et al., 2017; Windolf \& Nollert, 2001) indicate that UK company network was at its most cohesive and densest sometime during the period from the early 1950 s to the mid1970s.

Interpreting the increasing number of inter-company relations as an indicator of an increasingly well-integrated British business elite and a more relationship-based way of doing business, we would expect the impact of network ties on firm-level practices — such as patterns of corporate finance - to be strongest during this phase. We formally test this 
expectation by investigating whether there is a link between a given firm's interlocking patterns and its borrowing behaviour.

Table 3 summarises the results from the OLS estimation for our first period using the average distance of the focal firm from financial sector firms as independent variable. The results partly confirm our expectations, showing the expected and significant impact of the network embedding of a firm on its borrowing behaviour in 1976 when network density peaked. The significant and negative coefficient indicates that the further a company is from financial sector firms in terms of interlocks, the lower its level of debt will be. No such effect exists in 1958, when the network was still emerging or in 1983 when it had started to decline again. The effect was even positive, albeit only very marginally significant (at the 0.1 level), in 1950. This lends support to the view that over the period 1950 to 1976 network ties became more important. ${ }^{6}$

[Insert Table 3 about here]

Table 4 reports the results for the autoregressive network model investigating the network effect on firm debt levels ${ }^{7}$. For 1958, 1976, and 1983 the network effect is significant and shows the expected negative sign. These results suggest that a firm's financing practices are shaped by other companies it is connected to through its network. This effect is weaker the further removed the connected firms are, as the negative sign on the network coefficient suggests.

Interpreting these results substantively-how the network effect impacts on borrowing - is difficult, however, as being connected to a company that borrows much (little)

\footnotetext{
${ }^{6}$ The fact that we do not find any relationship corresponding to that in 1976 for 1958 and 1950 may also be due to the limitations of our data. Due to restricted availability, the samples for analysis for these two years are smaller. However, this would lead us to underestimate the impact of network ties on borrowing during this period, which goes against our hypothesis.

${ }^{7}$ Due to inconsistent financial reporting in 1950, the number of observations is too low to provide meaningful results. We therefore do not report results for that year.
} 
does not necessarily have to mean that the focal firm borrows much (little) too. Rather, the network effect may have to do with financial expertise, which may mean that being connected to a firm with such expertise leads the focal firm to choose the 'right' level of debt for its particular circumstances, rather than simply emulating the other's financial choices (see Mizruchi et al., 2006). Therefore, the important point with these results is not so much whether connections lead to more or less borrowing, but that the position in the network does influence companies' borrowing behaviour for the two post-war benchmarks 1958 and 1976 and that the strength of the association has increased between the 1950s and the 1970s.

[Insert Table 4 about here]

The election of the Thatcher government in 1979 and the 'big bang' reforms in 1986 marked the beginning of a new phase in British banking and of new corporate finance strategies. Our own results on the evolution of the corporate network support this notion. The four post-'big bang' benchmark years show a marked change in the network. Compared to 1983, the cohesiveness of the network bounced back over the next three decades, with a constant increase in the size of the main component, peaking at 89\% in 1997 and remaining above $80 \%$ thereafter. The UK interlocks network thus remained encompassing throughout the period analysed. This is reflected in the mean degree, which had dropped from a maximum of 4.15 in 1976 to 3.04 in 1983, but increased again to above 3.00 for the $1990 \mathrm{~s}$ and 2000s.

One explanation for the relatively encompassing network during the 1990s and 2000s may have to do with emerging corporate governance norms and in particular minimum quotas for independent directors and targets for women on boards. Evidence from other countries has shown how such quotas create constrained markets for directors, boosting networks and creating a new wave of 'big linkers' (Huse, 2016). This may lead to the creation of new ties in the network, without necessarily implying a similar functionality as in 
'traditional' company networks (Ferraro, Schnyder, Heemskerk, Corrado, \& Del Vecchio, 2012). Given that the UK has been at the forefront of the corporate governance movement since the 1990s, it is very likely that a similar process explains the features we observe.

Despite this relative stability in the basic network cohesion, however, the network's structure changed in important ways that may have affected its conduciveness to information flows and thus hide a considerable change in its functionality.

[Insert Table 5 about here]

Thus, the mean distance - measuring conduciveness for information flows - increased to just under 4.00 in the 1990 s and over 4.00 in the 2000 s. Importantly, for our purpose, the role of financial firms seems to have changed significantly in the network, shifting from cornerstones of the network to becoming virtually irrelevant for network cohesion by 2010 (Table 5). While in 1983 still a large majority of the most central companies were active in the financial sector (eight out of ten), they were only a minority from the 1990s onwards (three or four out of ten). This trend, despite the relative resilience of other network features, may affect the impact of network ties on corporate borrowing.

To test this effect, we performed the same regression analyses for the second period. Table 6 summarises the OLS estimates with the distance from financial companies measure as independent variable and the debt by assets measure as dependent variable. While we found some evidence for an impact of distance for financial firms on corporate debt levels in 1950 and 1976, the results reported in Table 6 do not provide any evidence of such a relationship for the period 1993-2010. It would hence seem that the connections to financial sector firms do not play a major role during this period, supporting our third hypothesis.

Table 7 reports the results for our spatial regression, which tests for the broader network effect. The results show that the network effect became non-significant for the whole 
period (with the partial exception of 1997 where it is very marginally significant at the 0.1 level). These results suggest that after the $1980 \mathrm{~s}$, the financing behaviour of connected firms stopped influencing the finance decisions of the focal firm. In other words, our results are consistent with hypothesis 3 and the view that from the mid-1980s to date, networks stopped to matter altogether for corporate finance in the UK.

It is interesting to note that 1983 constitutes a year where the network had considerably dropped in cohesiveness and density, yet network ties still mattered, while they did not matter anymore in later years despite the network having 'rebounded' to some extent in terms of cohesion and density. This illustrates our point that structural features are not sufficient to understand network function. Considering the impact of ties on practices reveals that the function may remain constant despite structural changes (compare 1983 to 1976), or conversely, the function of the network may change despite some structural similarities of the network (compare 1958-76 to 1993-2010).

[Insert Tables 6 and 7 about here]

\section{Conclusions}

This study constitutes to our knowledge the first systematic, direct, and longitudinal analysis of the impact of network ties on UK companies' finance patterns. Contrary to previous studies, we use a mixed methods approach combining the mapping of the network with a historical narrative and regression analysis.

Our study reveals that distinguishing the structure and the function of the network is important, because the two do not always evolve in synchronized fashion. Thus, while we find a considerable decline in network ties already from the mid-1970s to the early 1980 s, we show that the functional impact of network ties on lending patterns only changed sometime during the 1980s. Similarly, while the network remained relatively stable and encompassing during the 1990s and 2000s, the position of financial institutions in it had changed and the 
impact of network ties on company's financial practices had disappeared. Studies focusing solely on the structure of the network (e.g. Wilson et al., 2017), may hence miss important functional aspects of interlocking ties.

Our findings parallel those of Mizruchi et al. (2006) based on the US company network between 1973 and 1993. They find a declining network effect in the US since the 1970s similar to what we observe in the UK. Mizruchi et al. (2006) explain this phenomenon with the professionalisation and internalisation of corporate finance. As companies build up increasing internal financial expertise and capabilities, they rely less on banks and other financial institutions to provide financial expertise and access to different types of finance, which may explain the declining impact of external network ties on corporate finance decisions. Our findings are consistent with such an evolution for the UK as well. Indeed, while direct evidence is scarce, the literature suggests that — just like in the US-large UK companies increasingly financialised their strategies from the 1980s, including substituting un-mediated finance for mediated forms (Froud et al., 2006).

However, this should not lead us to overlook the distinct aspects of the UK case. Unlike their American counterparts, British banks were never great providers of long-term debt to industry, the network was sparse even at its peak in the $1970 \mathrm{~s}$, and the impact of finance-industry ties on corporate finance was only significant during a relatively short period of time. Indeed, while the post-war era marked a domestic reorientation of British finance that was accompanied by the most extensive corporate networks the country has seen in its modern history, the City's inward turn occurred not on its own volition, but as a result of severe regulatory and economic constraints. It was thus somewhat reluctant, and the City did not engage as deeply as their American, German or Japanese counterparts, refusing to extend long-term lines of credit. Nevertheless, we still find some evidence that during this period, network ties played a role in corporate finance. However, as soon as the regulatory 
'shackles' were removed during the 'big bang,' British finance resumed its historically conditioned international orientation.

\section{Acknowledgements}

The dataset we used for this study is the result of a multi-year collaborative effort that has been financed by funds from King's College London and Newcastle University Business School, which we acknowledge gratefully. 


\section{References}

Battilossi, S., \& Cassis, Y. (Eds.). (2002). European Banks and the American Challenge. Oxford University Press.

Bordo, M., \& Sylla, R. (Eds.). (1995). Anglo-American financial systems: institutions and markets in the twentieth century. Irwin.

Braggion, F. (2005). Credit market constraints and financial networks in late Victorian Britain. Working Paper.

Brandeis, L. (1914). Other People's Money and How the Bankers Use It. New York: Harper.

Cain, P. J., \& Hopkins, A. G. (1993). British Imperialism. Longman.

Cassis, Y. (1985). Bankers in English Society in the Late Nineteenth Century. The Economic History Review, 38(2), 210-229.

Chandler, A. D. (1990). Scale and Scope. Harvard University Press.

Collins, M. (1995). Banks and Industrial Finance in Britain, 1800-1939. Cambridge University Press.

Committee of London Clearing Bankers. (1978). The London Clearing Banks. Committee of London Clearing Bankers.

Conyon, M. J., \& Muldoon, M. R. (2006). The Small World of Corporate Boards. Journal of Business Finance \& Accounting, 33(9-10), 1321-1343.

Conyon, M. J., \& Shipilov, A. (2012). Is There An Anglo-Saxon Model? In B. M. Kogut (Ed.), The Small Worlds of Corporate Governance. MIT Press.

Cronin, B. (2011). Networks of corporate power revisited. Procedia - Social and Behavioral Sciences, 10, 43-51.

David, T., \& Westerhuis, G. (Eds.). (2014). The Power of Corporate Networks. Routledge.

Davis, G. F., \& Mizruchi, M. S. (1999). The Money Center Cannot Hold: Commercial Banks in the U.S. System of Corporate Governance. Administrative Science Quarterly, 44(2), 215.

Deeg, R., Hardie, I., \& Maxfield, S. (2016). What is patient capital, and where does it exist? Socio-Economic Review, 14(4), 615-625.

de Nooy, W., Mrvar, A., \& Batagelj, V. (2011). Exploratory Social Network Analysis with Pajek. Cambridge University Press.

Ferraro, F., Schnyder, G., Heemskerk, E. M., Corrado, R., \& Del Vecchio, N. (2012).

Structural Breaks and Governance Networks in Western Europe. In B. M. Kogut (Ed.), The Small Worlds of Corporate Governance. MIT Press.

Fiedler, M., \& Gospel, H. (2010). The Top 100 Largest Employers in UK and Germany in the Twentieth Century. Data (ca. 1907, 1935/38, 1955/57, 1972/73, 1992/95). Cologne Economic History Papers.

Financial Times. (2012, February 13). Misguided Merlin. Financial Times.

Fitch, R., \& Oppenheimer, M. (1970). Who rules the corporations? Socialist Revolution, 4, 73-108.

Fohlin, C. (2007). Finance Capitalism and Germany's Rise to Industrial Power. Cambridge University Press.

Fohlin, C. (2012). Mobilizing Money. Cambridge University Press. 
Franzese, R. J., \& Hays, J. C. (2004). Modeling International Diffusion. WZB Markets and Political Economy Working Paper Series, 47.

Froud, J., Johal, S., Leaver, A., \& Williams, K. (2006). Finacialization and strategy. Narrative and numbers. Oxon and New York: Routledge.

Gerschenkron, A. (1962). Economic backwardness in historical perspective. Belknap Press.

Granovetter, M. S. (1973). The Strength of Weak Ties. American Journal of Sociology, 78(6), 1360-1380.

Hall, P. A., \& Soskice, D. W. (Eds.). (2001). Varieties of Capitalism: The Institutional Foundations of Comparative Advantage. Oxford University Press.

Haunschild, P. R. (1993). Interorganizational Imitation: The Impact of Interlocks on Corporate Acquisition Activity. Administrative Science Quarterly, 38(4), 564.

Hilferding, R. (1968). Das Finanzkapital. Europäische Verlagsanstalt.

Huse, M. (2016). The "Golden Skirts": Lessons from Norway about Women on Corporate Boards of Directors. Routledge.

Jones, C., \& Cohen, N. (2012, February 13). Lending conditions are worse than Merlin suggests. Financial Times.

Kennedy, W. P. (1987). Industrial Structure, Capital Markets and the Origins of British Economic Decline. Cambridge University Press.

Konzelmann, S., Fovargue-Davies, M., \& Schnyder, G. (2012). The faces of liberal capitalism: Anglo-Saxon banking systems in crisis? Cambridge Journal of Economics, 36(2), 495-524.

Kotz, D. M. (1978). Bank Control of Large Corporations in the United States. Univ of California Press.

Kroszner, R., \& Strahan, P. (2001). Throwing Good Money After Bad? Board Connections and Conflicts in Bank Lending (pp. 1-40). Cambridge, MA: National Bureau of Economic Research.

La Porta, R., Lopez-de-Silanes, F., Shleifer, A., \& Vishny, R. W. (1998). Law and Finance. Journal of Political Economy, 106(6), 1-43.

Laeven, L. (2001). Insider Lending and Bank Ownership: The Case of Russia. Journal of Comparative Economics, 29(2), 207-229.

Larson, M. J., Schnyder, G., Westerhuis, G., \& Wilson, J. (2011). Strategic responses to global challenges: The case of European banking, 1973-2000. Business History, 53(1), $40-62$.

Lawson, N. (2006). Foreword (pp. i-v) In Big Bang 20 years on: New challenges facing the financial sector. Centre for Policy Studies.

Marquis, C. (2003). The Pressure of the Past: Network Imprinting in Intercorporate Communities. Administrative Science Quarterly, 48(4), 655-689.

Mintz, B. A., \& Schwartz, M. (1985a). The Power Structure of American Business. University of Chicago Press.

Mintz, B. A., \& Schwartz, M. (1985b). The Power Structure of American Business. University of Chicago Press.

Mizruchi, M. S. (1996). What Do Interlocks Do? An Analysis, Critique, and Assessment of Research on Interlocking Directorates. Annual Review of Sociology, 22(1), 271-298. 
Mizruchi, M. S., \& Stearns, L. B. (1988). A Longitudinal Study of the Formation of Interlocking Directorates. Administrative Science Quarterly, 33(2), 194.

Mizruchi, M. S., \& Stearns, L. B. (1994). A Longitudinal Study of Borrowing by Large American Corporations. Administrative Science Quarterly, 39(1), 118.

Mizruchi, M. S., \& Stearns, L. B. (2002). Social Networks, CEO Background, and Corporate Financing: A Dyadic Analysis of Similarity of Borrowing by Large U.S. Firms, 19731993. Unpublished Manuscript.

Mizruchi, M. S., Stearns, L. B., \& Marquis, C. (2006). The Conditional Nature of Embeddedness: A Study of Borrowing by Large U.S. Firms, 1973-1994. American Sociological Review, 71(2), 310-333.

Morgan, E. V., \& Thomas, W. A. (1962). The stock exchange. Elek Books.

Musacchio, A., \& Read, I. (2007). Bankers, Industrialists, and their Cliques: Elite Networks in Mexico and Brazil during Early Industrialization. Enterprise and Society, 8(4), 842880.

Musacchio, A. (2009). Drawing links between Corporate Governance and Networks: Bankers in the Corporate Networks of Brazil, Mexico, and the United States Circa 1910.

Entreprises Et Histoire, 54(1), 16-36.

Pollard, S. (1992). The Development of the British Economy, 1914-1990. E. Arnold. Rajan, R. G., \& Zingales, L. (1996). Financial Dependence and Growth. NBER Working Paper, (5758), 1-48.

Ratcliff, R. E. (1980). Banks and Corporate Lending: An Analysis of the Impact of the Internal Structure of the Capitalist Class on The Lending Behavior of Banks. American Sociological Review, 45(4), 553.

Richardson, R. J. (1987). Directorship Interlocks and Corporate Profitability. Administrative Science Quarterly, 32(3), 367.

Rubio-Mondéjar, J. A., \& Garrués-Irurzun, J. (2016). Economic and Social Power in Spain: corporate networks of banks, utilities and other large companies (1917-2009). Business History, 58(6), 858-879.

Schnyder, G., \& Wilson, J. (2014). The Structure of Networks: The Transformation of UK Business 1904 - 2010. In T. David \& G. Westerhuis (Eds.), The Power of Corporate Networks. Routledge.

Scott, J. (1987). Intercorporate Structure in Britain, The United States and Japan. Shoken Keizai, (160), p51-64.

Scott, J., \& Griff, C. (1985). Bank Spheres of Influence in the British Corporate Network. In F. N. Stokman, R. Ziegler, \& J. Scott (Eds.), Networks of Corporate Power (pp. 215233). Polity Press.

Selznick, P. (1949). TVA and the Grass Roots. University of California Press.

Slaughter \& May. (2014). Breedon + 2 years: Where are we now? Current non-bank lending options for UK corporates. Slaughter and May Briefing, (August), 1-8.

Stanworth, P., \& Giddens, A. (1975). The Modern Corporate Economy: Interlocking Directorships in Britain, 1906-1970. The Sociological Review, 23(1), 5-28.

Stearns, L. B. (1986). Capital market effects on external control of corporations. Theory and Society, 15, 47-75. 
Stearns, L. B., \& Mizruchi, M. S. (1993). Board Composition and Corporate Financing: The Impact of Financial Institution Representation on Borrowing. Academy of Management Journal, 36(3), 603-618.

Sylla, R. (2002). Financial Systems and Economic Modernization. The Journal of Economic History, 62(2), 277-292.

Thomas, W. A. (1978). The Finance of British Industry, 1918-1976. Routledge.

Thompson, P. (1997). The pyrrhic victory of gentlemanly capitalism: The financial elite of the city of London, 1945-90, Part 2. Journal of Contemporary History, 32(4), 427-440.

Turner, J. D. (2014). Banking in Crisis. Cambridge: Cambridge University Press.

Utton, M. A. (1982). The Political Economy of Big Business. M. Robertson.

van der Zwan, N. (2014). Making sense of financialization. Socio-Economic Review, 12(1), 99-129

Vasta, M., \& Baccini, A. (1997). Banks and industry in Italy, 1911-36: new evidence using the interlocking directorates technique. Financial History Review, 4(2), 139-159.

Vasta, M., Drago, C., Ricciuti, R., \& Rinaldi, A. (2017). Reassessing the bank-industry relationship in Italy, 1913-1936: a counterfactual analysis. Cliometrica, 11(2), 183-216.

Wasserman, S., \& Faust, K. (1994). Social Network Analysis. Cambridge University Press.

Westerhuis, G. (2014). The Dutch Corporate Network: Considering its Persistence. In T.

David \& G. Westerhuis (Eds.), The Power of Corporate Networks. Routledge.

Whitley, R. (2007). Business Systems and Organizational Capabilities. Oxford University Press.

Wilson, J. F., Buchnea, E., \& Tilba, A. (2017). The British corporate network, 1904-1976:

Revisiting the finance-industry relationship. Business History, 3(1), 1-28.

Windolf, P. (2005). The Emergence of Corporate Networks in Germany and the United States 1896-1938. Working Paper.

Windolf, P., \& Nollert, M. (2001). Institutions, Interests, and Corporate Networks. A Comparative Analysis. Politische Vierteljahresschrift, 42(1), 51-78. 